\title{
The Impact of E-CRM on Customers Attitude and Its Association with Generating Competitive Advantages in Iranian Financial B2B Context
}

\author{
Rozita Shahbaz Keshvari \\ MBA Graduated From Sharif University of Technology, IC, United States \\ Tel: 91-22-838-353Ｅ-mail: Rozita.ShK@GMX.com
}

Received: August 15, 2011

Accepted: February 27, 2012

Published: April 1, 2012

doi:10.5539/ibr.v5n4p34

URL: http://dx.doi.org/10.5539/ibr.v5n4p34

\begin{abstract}
In the emerging competitive and technological driven banking era, banks have to strive hard for retaining and enlarging their customer base. Electronic customer relationship management (E-CRM) is the combination of traditional CRM with the e-business applications marketplace. An E-CRM system provides financial institutions with the opportunity to establish individual and need oriented customer relationships. E-CRM enables the financial institutions to provide the right financial product at the right time (Sascha, 2003). Focus of this paper is to explore E-CRM benefits that have positively effects on customer satisfaction and association between them in Iran Financial Institutions. The findings indicates that Proliferation of channels (e.g. Internet), Up to date of banks, Services quality, International customers' satisfaction, Improve cash flow management, Safety and Transaction security have positive effects on customer satisfaction. Furthermore, it seems that there is significant association between Quality factor and Safety factor and also between Infrastructure improvement and Customer responsiveness.
\end{abstract}

Keywords: Electronic customer relationship management (E-CRM), Competitive advantages, Business to business (B2B)

\section{Introduction}

The service industry, especially financial institutions grapples with increasing competition currently. In such environment, differentiation is necessary and banks begin to realize that no bank can offer all products and be the best/leading bank for all customers. They are forced to find a new basis for competition and they have to improve the quality of their own products/services (Zineldin, 1996). Nowadays, financial institutions will not only confined to borrowing collection of savings and lending loans, but also forced to learn the advanced and modern rules and tools to provide convenience environment for their customers and satisfy their needs.

Recently it has been acknowledged that company relationships with customers can be greatly improved by employing information technology (Karimi, 2001) which can facilitate and enhance customer relationships in various ways but mainly enables companies to attain customization, which is the essence of a customer-centric organization (Stefanou, 2003). Relationship marketing is becoming important in financial services (Zineldin, 1995). If a bank develops and sustains a solid relationship with its customers, its competitors cannot easily replace them and therefore this relationship provides for a sustained competitive advantages (Gilbert \& Choi, 2003).

In the early 1990s, the concept of relationship marketing was formally introduced into the services marketing literature. Financial services institutions, airlines and other service providers found it profitable to retain and reward existing customers rather than run after new customers (Mittal \& Kumra, 2001).

E-CRM is defined as a mean of selling, serving, or communicating with customer through the web. Further he takes E-CRM as a subset of CRM, which means that E-CRM is one of the channels that a company can use to deploy its CRM strategies (Dyche, 2001). The goal of E-CRM system is to improve customer service, retain valuable customers and to aid in providing analytical capabilities within an organization (Fjermestad, 2003).

Business to business and the move to electronic transactions is allowing corporate to gain efficiencies, reduce costs, streamline business processes and provide their products and services to a larger customer base. Business to business e-commerce migrate the traditional business model towards the emerging digital marketplace (Duckett, 2001). According to Morris, Relationship marketing as a concept is widely embraced by industrial marketers, today it's time for relationships, particularly in business markets (Morris, 1998). 


\subsection{Research Problem}

Confronted with the fierce competition in the internet age and today telecommunication marketplace goes to banks grapple with difficulties for survival when the customer is having access to a variety of products and services. Due to some problems occurred in this situation such as: customer inquiries are not provided and transactions become complicated, the customers' expectations and requirements are changed. They need the organizations which utilize different electronic technologies like call centers, ATMs, voice response systems and etc., to satisfy their need with the best quality fast and in the cost effective way (Puccinelli, 1999).

"Managers really need to look at areas where opportunities lie because industry consolidation, virtual delivery channels and the ability to move money around at the click of a mouse are making it easier for customers to pack their bags and say bye to the bank" (Puccinelli, 1999, pp 48). For providing high quality of customers service, Of course, technological capabilities are not adequate (Dyche, 2001). Accordingly, analyzing of the business situation and understanding the requirements for automation are two basic steps for companies which focus on customer service (Xu, 2002).

In this difficult and demanding situation, adoption of the internet and availability of electronic channels of communication, are becoming possible and significant way to gather customer related information with the aim of building customer database. Through the using of high advanced electronic communications tools and E-CRM applications, the organizations can handle and manage customer interactions over these new electronic channels of communications (Mittal \& Kumra, 2001).

Unexpectedly there is a lack of scientific research toward E-CRM that focuses principally on the advantages of it in banking sector. Therefore, for well awareness of the target customers and building profitable and long term relationship with the manager of the financial institutions and them, we have formed the problem area as: "Gaining Competitive Advantages on E-CRM In Financial Institutions in Iran through B2B Model" to better understanding of the E-CRM and its advantages.

\subsection{Overall Research Purpose}

Regarding the reasoning above, the purpose of this study is to examine the competitive advantages on E-CRM in financial institutions. A primary purpose of management and marketing strategy is to develop a competitive advantage which provides customers with superior value compared to competitive offerings, thereupon to justify this purpose; two main objectives are followed in this study, which contain:

1. What are the core attributes constructing the E-CRM in Financial Institution that have positively effects on business customer satisfaction?

2. To understand the association between E-CRM benefits and competitive advantages in Financial Institution.

\subsection{Research Hypotheses}

In this study, following hypotheses are going to be examined. They are:

$\mathrm{H}_{1}$ : E-CRM benefits have positive effect on customers' satisfaction.

$\mathrm{H}_{2}$ : E-CRM competitive advantages have positive effect on customers' satisfaction in choosing the banks to do their financial and business works.

\subsection{Key Concepts}

Customer Knowledge: "Customer knowledge is the collection of information and insight that your business has built up over time and needs to use to leverage successful customer relationships and provide the products and service that those customers need." (Note1)

Marketing Strategy: "It is a written plan (usually a part of the overall corporate plan) which combines product development, promotion, distribution, and pricing approach, identifies the firm's marketing goals, and explains how they will be achieved within a stated timeframe." (Note 2)

Service Quality: The quality of a service is subjectively perceived by customers during the interactions with an organization (Grönroos, 2000). Parasuraman defined service quality as "the consumers' judgment about a firm's overall excellence or superiority". (Parasuraman et al., 1988)

Data Warehouses: The system serves as a single repository of data. When data warehouse is up and running with clean data, it provides a single version of a customer or group of customers. The appropriate query and analysis tools and data mining software enable a business to make a better understanding of its customers' needs (Dar \& Hu, 2005). 
Call Center Automation: A call center has the ability to handle large volumes of customer and other telephone calls. It screens the calls, routes them to a qualified person or automated response, and logs all interactions. Improving efficiency, customer service, and oversight while lowering the overall costs associated with a customer contact center are determined as principle aims of a call center. (Note 3)

Marketing Automation: Marketing Automation enables businesses to more effectively manage multi-channel campaigns. Collecting and integrating customer data, captured from multiple sources lead to the organization plans, manage and execute focused marketing campaigns across multiple channels (email, direct mail, messaging, Web,etc.). (Note 3)

Sales Force Automation: Sales Force Automation is a best practices process that uses software to automate the business tasks of sales while providing sales agents with access to contact details, appointments, sales opportunities, customer purchase history, order management, territory overview in real time. (Note 3)

Service and Support Automation: The ultimate goal of Customer Service and Support Automation is to increase customer value while reducing the cost of doing business. As an integral part of CRM, Customer Service and Support allows organizations to manage business relationships effectively so as to improve and sustain customer loyalty and retention while reducing overall business expenditures. (Note 3)

Cash Flow Management: It is the process of monitoring, analyzing, and adjusting your business' cash flows. The most important aspect of cash flow management is avoiding extended cash shortages, caused by having a too great gap between cash inflows and outflows. "You won't be able to stay in business if you can't pay your bills for any extended length of time". (Note 4)

Campaign Management: The campaign management process continues to increase in difficulty, with marketers having to ask increasingly complex questions such as:

- How many leads are needed for sales to hit its target?

- Based on historical performance, how many leads are realistic based on my budget?

- What is the right mix of offers, messages, and tactics?

In addition to these questions, effective tactics within go-to-market channels are constantly changing, requiring marketers to understand the subtleties of email, and web-based campaigns. Campaign managers need to plan campaigns diligently but be ready to adapt quickly based on response rates or changing channel dynamics. (Note 5)

Search Ability: Search engine optimization involves a website's presentation, structure and coding. The site should be "search engine friendly" in terms of design, menus and content. (Note 6)

Search ability is one of the implementation E-CRM benefits in financial institutions which help everyone to find for example one of their old accounts everywhere.

Customer Segmentation: Segmentation helps banks target the right prospects and offer the right services to their customers. Segmentation and targeting based on customer profiles is becoming increasingly important. Customer segmentation is the subdivision of a market into discrete customer groups that share similar characteristics. It can be a powerful tool to identify unmet customer needs. Companies that identify underserved segments can then outperform the competition by developing uniquely appealing products and services. (Note 7)

Customization: It is a useful service that separate one similar product or service from another. By accurate customization, the better you can provide personalized individual service the more customers you will attract.

Unraveling Complexity in Products and Services: Walk into any bank, or insurance agency, you will see complexity at work: More products and services are available to consumers than ever before. But, as businesses increase their product and service portfolios in response to evolving customer demands or through mergers and acquisitions, they run the risk of adding too much complexity, which can tax existing resources and ultimately harm returns. In this special situation, experts George Group Consulting and Wharton offer insight on how complexity can create considerable problems for companies often while remaining difficult to spot and suggest strategies for eliminating complexity or making it works to a company's advantage (Note 8).

\section{A Brief Literature}

This section focuses on providing the reader with the necessary information about the relevant literature that is related to this research problem. A collection of E-CRM benefits are presented also at the end of this part.

\subsection{According to "E-CRM in Indian Bank"}

According to (Mittal \& Kumra, 2001) Technology, people and customer are the three elements on which hinge the success of banking in the fast changing economic environment. The ultimate performance of a bank depends upon 
the satisfaction of its customers. They thought in the emerging competitive and technological driven banking era, banks have to strive hard for retaining and enlarging their customer base. E-CRM, which is the latest buzzword in the corporate sector, is perceived as one of the effective tool in this direction by the banks. Its emphasis is on defining the customers as valuable in the long-term and on viewing customer relationships as learning relationships. The concept of CRM, when seen in the context of e-business, it translates into e-CRM, which essentially deals with managing customer interactions over the web.

They analyzed the concept of e-CRM in Indian banks from its various dimensions covering specifically its need, process, present status and future prospects. In the first step, they investigated current status of e-CRM in Indian Banks and then looked for E-CRM Techniques which used by Banks in India. On the other hand, as currently internet have enabled banking at the click of the mouse, they wanted to investigate that Click and brick is the right method for Indian bank or not. There are five functional categories for online banking sites on line brochure center, interactive bank, e-mails, calculations and cyber banks, which offer customers access to account information, inter-branch funds transfer and utility bill payments. They surveyed the following banks in India: MTNL, BSES, ICICI Bank, HDFC Bank, Global Trust Bank and foreign banks, Citibank, Federal Bank, HSBC Bank, Deutsche Bank and ABN AMRO Bank UTI Bank.

They found out that Banks must build their brand image in assuring customers about the safety of their money and security of transaction on the Net. They concluded that the most useful E-CRM technologies which are used in Indian banks are: Internet banking, Data Warehousing and Data Mining, ATMs, Telephone banking or Mobile banking, computerized decision support system, E-mail, Computer networking and Customer smart cards. Furthermore, e-CRM based alone on Internet will seems to be a wrong strategy for banks in India. Jose Fonellosa of Spain BBVA, which acquired first e-CRM, says internet is at best a zero sum game for banks. For high end products, customer cannot only rely on e-banking. For social interactions, people would like to visit their traditional brick and mortar branches. Click and brick seems to be the right model which ultimately will succeed in India. Banks in India are on the learning curve of e-CRM and are trying to meet the latent needs of the customers. The success of e-CRM will depend upon the development of robust \& flexible infrastructure, e-commerce capabilities, and reduction of costs through higher productivity, lower complexity and automation of administrative functions.

\subsection{According to "Benefits of E-CRM for Banks and Their Customers: Case Studies of Two Swedish Banks"}

The customer relationship management (CRM) is essential and vital function of customer oriented marketing. Its functions include gathering and accumulating customer-related information in order to provide effective services. E-CRM is a combination of IT sector but also the key strategy to electronic commerce (Anumala \& Reddy, 2007). Bank customers form expectations derived from many sources Boulding proposed that customers form expectations of what will happen in their next encounters based on what they "deserve". (Boulding, 1993). Zeithaml and Bitner identify two levels of expectations, desired service and adequate service. Desired service represents the "wished for" level of performance and adequate service reflects showing more basic service expectations (Zeithaml, 2000). The model permits exploration of the perceived difference between expected service and the experienced service, particularly the zone of tolerance developed by Parasuraman, they're by customer specific benefits are: Customer interaction and satisfaction, Convenience, Speed of processing the transaction through e-Response, Trust, Service quality (Parasuraman, Berry \& Zeithaml, 1991).

They considered the following research questions how can the benefits of E-CRM for banks are described and how can the benefits of E-CRM for bank customers be described. They used a qualitative research approach Empirical data was collected through in-depth interviews were conducted with two Swedish banks and a group of their customers. According to the first research question their findings indicate that E-CRM enables financial institutions and organizations to maintain relationship with customers and both of the banks less use email for their business purpose and their Personalized and One to One Service are improved by implementing E-CRM. Moreover, to improve and maintain transactions security of the customers, the mentioned banks has latest techniques and technologies. They also investigated about the benefits of E-CRM for the customers and they found out Customer interaction and satisfaction is found to be an important benefit and Trust and Convenience is a major benefit provided to the customers of the banks. There are other advantages which they discovered them like: Speed at which the transactions have been processed and their rate of accuracy, Reliable employees, availability of the latest information technology.

\subsection{According to "Electronic Customer Relationship Management in Online Banking"}

Customers are getting more involved to use web because of the internet is becoming more available and customers are comfortable with web business, those customers who are not using Web will use tomorrow and those who have never purchased today will buy tomorrow on the web (Feinberg \& Kadam, 2002). To satisfy customers, companies 
should maintain consistency in all interaction channels like the Internet, E-mail, Telephone, and Web, Fax and company areas like sales, services, marketing and other fields. Traditional CRM has limitations to support outside channels while E-CRM supports marketing, sale and service (Shan \& Lee, 2003). In electronic and online environment, they investigated how banks use E-CRM tool to maintain their customer relations by using the Internet and what benefits are derived by using this E-CRM tool and how successfully this tool is implemented in a bank.

For their research purpose, they conducted two case studies of Sweden and Denmark banks. They found out two cases banks implemented and used E-CRM mostly for Mass Customization, Customer Profiting, Self Service, One to One interaction and Automatic locks in flow of financial data like Security which ultimately results in reduces cost of operation and increased customer loyalty and more profits. According to their third research question, their findings indicates that for a successful E-CRM implementation, Staff training and customer feedback are two tangible factors. In this part, the literature which is relevant to above discussion is summarized. (Table 1)

\section{Methodology}

In the previous part, a review of literature was presented. In this section, it will be covering the research process and methodology that will be used in this research work. Based on the research problem, the collections of methodology are presented to provide best answers for the research questions. At the end of each section, motivations and justifications of each adopted methodological option will be clarified.

\subsection{Research Purpose}

For any study research design looks like the framework which is used to collect and analyze data. Conducting a well research design brings about ensuring these facts that the study will be relevant to the problem and economical procedures will be used within this process. There are many research design frames, that are usually classified in three major parts: Exploratory, Descriptive or Casual (Churchill, 2010).

The purpose and research objectives of this research indicate that this study is descriptive and somewhat exploratory. As E-CRM is a new research area for the banks and financial institutions and also it is not possible to find similar research and studies which concentrate on our field of study, firstly it is described the area of the research and later explain the issues. Therefore, descriptive and exploratory research is suitable research designs for our study.

\subsection{Research Approach}

This section focuses on the approaches on which the research will be worked. The research approach can be either qualitative or quantitative. There are several characteristic about quantitative research, among them selectivity and distance to the object of research are the main ones. In comparison, qualitative approach is opposed and it is subjective in nature and is characterized by the closeness to the object of research (Zikmund, 2000).

While conducting our study we found that both qualitative and quantitative approaches fulfilling the requirements of this thesis. According to the base of this thesis that is based on scientific theories, we used deductive approach in our research. This research is started by using existing theories in the area of E-CRM due to the fact that it is appropriate to start up with the established theories to get a solidified substructure of research and to further construct the questions in the interview guide and questionnaires and then logically to draw conclusions based on the knowledge and empirical findings.

\subsection{Research Strategy}

There are different types of strategies that are available to choose for conducting the research. Denscombe determined five major research strategies: Surveys, Case Study, Experiment, Action Research, and Ethnographic (Denscombe, 2000).

The purpose of this study was to bring an insight and better understanding of the competitive advantages of E-CRM in Iranian financial institutions that impact of E-CRM on customers' attitude. Due to this reasons, we did not have and require control over behavioral events. Thereupon, both case study and survey are suitable choices for our study.

Survey and analysis are techniques in which the required information is gathered by distributing questionnaire among sample of people (Zikmund, 1994). On the other hand, surveys are advantageous when the researcher goal is to describe the incident or prevalence of a phenomena and also when it is to be predictive about certain outcomes (Yin, 1984). Moreover, in this study it was tried to answer 'what (which)' questions, so survey was very appropriate for this work.

\subsection{Sample Selection}

When conducting research, it is often impractical and impossible or too expensive to collect data from all the potential units of analysis included in the research problem. So, from smaller number of units, a sample, as often 
chose to represent the relevant attributes of the whole set of units. Due to the fact that samples are not perfectly representative of the population from which they are drawn, the researcher cannot be certain that the conclusions will generalize to the entire population (Graziano \& Raulin, 2004).

In this paper, convenience sampling was used to examine financial institutions which have some internet and electronic facilities and in the near future they will contemplate to implement E-CRM creating the long-term and profitable customer relationship with their customer through E-CRM technology such as internet, web and etc.

In regard to the business customers (Business customers are defined as customers who are staff of the organizations, banks or financial institutions and do their business works with bank by the envelopment of their organizations and have business relation with financial institutions or potential customers that need specific services from financial institutions), the questionnaire was distributed among four hundred ninety organizational customers and financial institutions' employee. As mentioned above, the convenience sampling is suitable choice in determining the sample size to be close to our desired results as much as possible in B2B context.

\subsection{Data Collection Methods}

According to Yin (1984), preparation for data collection can be complex and difficult. If they are not handled well, the entire case study investigation and all of the earlier work can be imperiled.

According to Churchill (2010), Structured-Undisguised questionnaire is the most typical questionnaire which is used very frequently in marketing research. This type of questionnaire consists of standardized and same wording questions for all respondents to ensure that all the candidates are replying to the same questions.

Based on the above discussion, it is used both types of data collection, primary and secondary data. Since face-to-face contact was the source of primary data and secondary data was collected through the census reports, relevant journals-national as well as the international pertaining to the topic of research, books, and business magazines and websites of banks and financial institutions.

As the study has both descriptive and exploratory nature, it is utilized the great instruments which are established upon execution of exhaustive face-to-face interview and structured-undisguised questionnaire.

The customers' questionnaire consists of three main parts, the first part contains seventeen questions about E-CRM benefits, the second part includes eleven questions about E-CRM competitive advantages and the last part has six questions about E-CRM technologies. All of the items of part one and two were measured by using five-Point Likert-type response scales anchored at 5 Very Important and 1 Unimportant.

\subsection{Data Analysis}

After data collection, for deciding what and which meaning can be attributed to the words, determining the implications and finding the relation of the attributes to the topic being investigated, the researcher should analyze the obtained data and findings (Denscombe, 2000).

The analysis has been conducted by using pervious theories and studies mentioned in section 2 that provided the base for data collection, analysis and comparison of this thesis. The findings were analyzed including the profile data of financial institutions and customers by considering the general strategy. Data reduction technique was used to identify more relevant data. Further, the acquired data of questionnaires have been analyzed by statistical package for social Sciences (SPSS 19) software. In Figure 1 all of the research methodology steps that were used in this paper.

\subsection{Research Quality Criteria (Validity \& Reliability \& Normality Test)}

Construct validity is recognized by the level by which it determines or confirms association of linked hypotheses produced from a theory, which relies on the concept. Construct validity can be depended upon the theoretical reason involved in concepts. In order to reach construct validity the researcher needs to have resolute meaning of the measure by launching what essential researchers call convergent validity and discriminant validity (Zikmund, 2000).

As mentioned above this research is to some extent are exploratory research, so the questions of this study are explored one by one from different and pervious study. In the first step, all the attributes and questions in English language are collected. Then, the attributes have been translated from English to Persian. In the next step, the attributes are specialized and translated from the regular words into language of banking system and marketing according to field of Iranian Financial institutions and culture.

In this research the significant attributes of E-CRM that provided customers' satisfaction of Iranian Financial Institutions are explored. Principle component analysis was used, since it was an exploratory factor analysis. The factor analysis was not only an efficient test for the validity of this research and reduction of attributes, but also was 
best analysis to determine the most important attributes and the independence among them. For both constructs of our study, factor analysis is conducted. The results represent as follow:

- E-CRM benefits affecting customers' satisfaction.

In this study, seventeen benefits of E-CRM are explored by considering other authors' opinion about E-CRM benefits including as obviously showed in below table to find out which of these benefits are affecting customers' satisfaction. (Table 2)

The initial factor analysis was run using principle component analysis method in SPSS window. The result were not satisfactory, as some of the attributes showed an extraction value below 0.5 , which was taken as the minimum level for acceptance, thus after successive removal of attributes with low extraction value, it was found that a solution containing 7 variables gave a high KMO (MSA: Measure of Sampling) value of 0.920 (Table 3).

As shown in table above, KMO statistic variable is 0.920 (it is near to 1) that let to run factor analysis for this research. For these two constructs, it is necessary to measure internal reliability of them.

Ten benefits were rejected from the original selection of seventeen attributes. In addition, to test the internal reliability, the Cronbach's alphas of the seven attributes were calculated. The obtained alpha was larger than 0.4 (a level considered acceptable in most research) (Table 4).

For satisfying the customers' requirements, retaining the valuable customers and attract the new ones, financial institutions should consider these seven elements which were mentioned above.

- E-CRM competitive advantages affecting on Customer satisfaction in choosing the banks to do their financial and business works.

The competitive advantages of E-CRM which were tested in this study are shown in Table 5, like the pervious section, the initial factor analysis was run using principle component analysis method in SPSS window. The result indicated that some of the attributes have extraction value lower than 0.5. By continuous attributes removing that have low extraction value, 5 competitive advantages were obtained with the KMO of 0.859 (Table 5 and Table 6).

According to six removal steps to obtain the MSA with the value of more than 0.5 , finally five competitive advantages were accepted that the Cronbach's alphas of them were 0.762 (Table 7).

As mentioned in the above table, the Cronbach's alphas of both parts are lower than 0.4 (a level considered acceptable in most research), so the constructs of this paper are relaible.

After exploring the factors and determining their related questions, I compute the score of each variable by using Compute technique towards the means of attributes. Later, to test the normality it seems that Sample Kolmogorov-Smirno (K-S) Test is the best method.

The findings indicate the sig. of all the factors are lower than 0.05 , therefore, none of them have the normal distribution. (Table 8)

\section{The Finding Sections}

\subsection{Business Customers' Information}

According to the four hundred ninety business customers who participated in the survey, the majority of them were male $(65.3 \%)$. The majority of assigned people as the financial institutions' business customers were at the age of 30 t0 40 and partly between 20 to 30 (160 persons), that implies most of the business customers are young and the tendency of these young people to implementation of E-CRM in Iran financial institutions is more than other business customers who are younger than 20 or older than 40 .

The most percentage of business customers $(66.7 \%)$ are belonged to those customers who have business relationship with the financial institutions more than 5 years. Thus, the more the finical institutions provide advanced service and manage their relationship with their customers in best way, the more customers' satisfaction and loyalty are obtained.

\subsection{Benefits of E-CRM}

As motioned in the section 3, we explore seven benefits of E-CRM by considering other authors' opinion about E-CRM benefits to find out which of these benefits are the most important benefits in implementation of E-CRM in Financial Institutions in Iran; these benefits include: Up to date of banks, Services quality, International customers' satisfaction, Transaction Security, Proliferation of channels (e.g. Internet), Improved cash flow management and Increasment of Safety. 


\subsubsection{The Most Significant Benefits of E-CRM}

In this part for better understanding that all the benefits have the same importance in customers' viewpoints, we used Friedman Test. The Friedman test is the non-parametric alternative that can be used to test differences between groups when the dependent measured variable is ordinal. It compared the mean rank the related factors and indicated how the factors differed.

As the sig. is 0.000 and is less than 0.05 , so $\mathrm{H} 0$ is rejected. It implies these benefits do not have the same importance in customers' viewpoints. As it shows in Table 9, Friedman test is ranking the attributes based on their importance. The least value in this test shows the most important attribute. The results of comparing the mean rank of benefits represent the five E-CRM benefits which have the highest importance among four hundred ninety business customers: Improved cash flow management, International customers' satisfaction, Proliferation of channel, Increasing safety and Service quality. (Tables 10 and Table 11)

\subsubsection{The Impact of E-CRM Benefits on Customer Satisfaction}

For this research, it has been considered several hypotheses that in this part the first hypothesis for determining and measuring important benefits of E-CRM implementation on customer satisfaction in Iran financial institutions is tested. To check the impact of benefits of E-CRM on customer satisfaction, the most appropriate method is Stepwise Linear Regression analysis, but before applying this test, we must test the normality as one of the necessary information to perform regression.

Stepwise multiple regressions are useful tool to describe the relationship between one 'predicted' (dependent) variable and a selection of 'predictor' variables (independent). This method brings about simplest equation with the best predictive power. (Note 9)

The results of normality test were accepted, as mean of attributes are close to zero and the standard deviation showed a value close to one. After analysis the findings in following table indicate that mean is 0.009 which is close to zero and the standard deviation equals to 1.003 that closed to one. Thereupon, the distribution of errors is approximately normal. (Table 12)

Normality in regression part allowed us to do regression analysis for testing the impact of benefits of E-CRM on customer satisfaction. In Step wise method, the independent variables are not in the equation which have the smallest probability of $\mathrm{F}$ is entered, if that probability is sufficiently small. Variables already in the regression are removed if their probability of $\mathrm{F}$ becomes sufficiently large. This method stops when no more variables are eligible for removal (Hartman, 2000). Therefore, in this thesis, the results indicate that from the seven explored E-CRM attributes, four of them have sufficient probability to enter, so they have more influence on satisfying of customers: Increasing safety, Proliferation of channels, Up to date of banks and Transaction security.

Regarding to Beta value and P-value (sig.), we can say that increasing safety has the most impact on customers' satisfaction. It means by unitage variation in safety, 0.479 variations are occurred in customers' satisfaction (Beta $=$ 0.479 and P-value $<0.05$ ). Consequently, the first research hypothesis is accepted. (Table 13)

\subsubsection{The Association between E-CRM Benefits in Iran Financial Institutions}

As the seven mentioned explored benefits of E-CRM did not have normal distribution, for testing the consistency of all the factors, it has used Spearman Correlation analysis.

Under this, correlation of every item with the total of major and the computed value is compare with the standard value .0159. If the captured value is found less than the standard value, then whole statement will drop and will be term as an inconsistency. But if the value is more than the standard value, it is termed as a consistency.

As it is shown in Table 14, due to this fact that the sig. of all attributes is less than 0.05 and the standard value of them are upper than 0.159 , there is positive correlation between the factors.

Moreover, for detecting the strong correlations between four independent variables, Multi-collinearity was used in logistic regression models. This may be due to good effects in that most customers who are feeling happy with the resolution of the problem will reflect back and state that the operator was friendly (Tang \& Weiner, 2005). Tolerance, Variance Inflation Factor, Eigen value and Condition Index are four essential indexes that determined the multi-collinearity of variables. Since for each independent variable, Tolerance $=1-\mathrm{R}$ square, where $\mathrm{R}$ square is the coefficient of determination for the regression of that variable on all remaining independent variables, low values indicate high multivariate correlation. The Variance Inflation Factor (VIF) is $1 /$ Tolerance, it is always $\geq 1$ and it is the number of times the variance of the corresponding parameter estimate is increased due to multi-collinearity as compared to as it would be if there was no multi-collinearity. Values of VIF exceeding 1 are often regarded as indicating multi-collinearity. (Allison, 1999) 
In addition, if the value of Eigen Value is near to zero and the value of Condition Index is more than 15, the multi-collinearity between variable will be enhanced. The findings detected that tolerance of variable are not very low and the Eigen value of three of them which indicated in following table are not close very much to zero. In this case, condition index of three elements are bigger than 15 that represent. According to the mentioned results, there is multi-collinearity between the independent variables, but due to this fact that the condition indexes of them are less than 30, there is no major problem in using regression. (Ghayomi, 2010) (Table 15)

Regardless of the mentioned reason for the correlation between the attributes, we need to find a modeling tool that is capable of determining the relative contribution of each of these attributes to overall satisfaction. The above discussion represent that customer satisfaction is function of four significant E-CRM benefits that three of them have small multi-collinearity correlation. The following model is shown the impact of E-CRM benefits on customers' satisfaction in Iranian Financial Institutions. (Figure 2)

\subsection{Competitive Advantages of E-CRM}

Implementation of Electronic Customer Relationship in financial institutes and banking systems brought several competitive advantages for both customers and banks. By understanding customers' requirements and finding which advantages are favorable and useful for customers, banks tend to compete for implementation of advanced electronic technology to attract and satisfy their needs.

The competitive advantages of E-CRM tested in this study as explored in pervious chapter are: Improvement integrated customer profitability, Decreasing response time, Improving response to customer activity, Utilization of Marketing and Strategic factors, Creating business structure.

\subsubsection{The Most Significant Competitive Advantages of E-CRM}

According to the discussion in the former section, the Friedman test is appropriate to test that there is no difference between the importance of the mentioned competitive advantages of E-CRM with each other and they have different importance in customers' viewpoint.

As the sig. is 0.000 and is less than 0.05 , so $\mathrm{H} 0$ is rejected. The findings are indicated that E-CRM competitive advantages don't have same importance in viewpoint of customers. (Table 16)

Based on the ranking results of Friedman test, the most significant attribute in implementation of E-CRM that brought about competitive advantages for Iranian Financial Institutions and business customers is creating business structure. It is worth to note that decreasing in response time has the lowest importance in opinions of business customer. (Table 17)

4.3.2 The Impact of E-CRM Competitive Advantages on Customers' Satisfaction in Choosing the Banks to Do Their Financial and Business Works

This section determined the vital E-CRM competitive advantages on customer satisfaction in Iran financial institutions in choosing the banks to do their financial and business works. Like the pervious section, first of all the normality test of regression is tested.

The results present that the normality in regression part were accepted, because the mean of competitive advantages was equal to zero and the standard deviation was very close to one. (Table 9)

The findings of Table 18 is a suitable reason for acceptation of the second hypothesis, it means that Improve integrated customer profitability and decrease of response time are two competitive advantages which have the highest impact on customers' satisfaction in choosing the banks to do their financial and business works while utilization of marketing and strategic factors is the factor that has a very poor influence on customers' satisfaction in choosing the banks to do their financial and business works.

4.3.3 The Association between E-CRM Competitive Advantages in Financial Institution in Iran

First of all, in this section the consistency of all the attributes was captured by applying items to Spearman Correlation analysis.

The findings indicate that all the competitive advantages have high correlation with each other. The correlations between these competitive advantages are shown in the Table 19. In this part, in order to find out which variables are nearly collinear with which other ones, we used the multi-collinearity test also. The outcomes indicate that tolerances of variable are not very low to make some problems in performing regression. On the other hand, Eigen values of three of them are close to zero and the Condition index of these attributes are more than 15 . 
Regard to the above discussion, although there are multi-collinearity between Creating business structure, Improve response to customer activity and Utilization of Marketing and Strategic factors, as the condition indexes of them are less than 30, there is no major problem in using regression. (Ghayomi, 2010)

Finally, the relevant model of competitive advantages' impact on customers' satisfaction in choosing the banks to do their financial and business works is presented.

\section{Conclusion}

In this new era technology and electronic society customer expect to use banking services in the shortest time in cost effective way, therefore customers are the elements which the banks and financial institutions are focusing on them to manage customer relationship and these improvements lead customers to determine that Improved cash flow management as the most important E-CRM benefits with highest priority. Regarding to this fact that in today banking system, transaction security, bring the banks up to date and safety are very poor, customers need improvement in these fields. Financial institutions should look for ways that people trust and success in customer satisfaction.

It is needless to say that, although all of the E-CRM benefits and also all of the E-CRM competitive advantages have positive association with each other, increasing safety has the most impact on customers' satisfaction. This element is the most efficient attribute that leads to attract customers' trust and satisfaction. Unsafe environment in banking sector prevents customers to do their transactions comfortably.

\section{Limitation}

Like most other studies, in this study there is a risk that some of the questions given in the questionnaire may have been misunderstood and misinterpreted. The questionnaire in this study included terms such as customer Interactivity and Knowledge, personalized services or one to one services, international customers' satisfaction, improved cash flow management, search ability which have professional meanings and are extracted from professional context but they may have other explanation in respondent's mind. Therefore, more description about few questions could be helpful that had paid attention to this point and contacted with the respondents one by one. On the other hand, distributing these questioners among different public/private organizations, financial institutions and banks in business to business context because of their heavy time schedules, difficulties and rules, is very hard and took a long time.

\section{Further Studies}

During this research, It has cleared that there can be much more researches in this field because financial institutions are more competitive in Iran and there are lots of opportunities to better understanding of customers and their requirements about modern and electronic technologies. This study has provided some attractive choices for researchers who would like to investigate for new subjects or involve in this expanded field: E-CRM benefits and competitive advantages in financial institutions and banking sector.

\section{References}

Allison, P. D. (1999). Logistic Regression Using the SAS System. Cary, NC, USA: SAS Institute Inc.

Anumala, S., \& Reddy, S. K. K. (2007). Benefits of e-CRM for Banks and their Customers: Case studies of two Swedish banks. (Master Thesis). Department of Bussiness Administration and Social Sciences, Luleå University of Technology.

Awad, E. M. (2000). The Structure of E-Commerce in the Banking Industry. New York, NY, USA: ACM.

Boulding, W., Kalra, A., Staelin, R., \& Zeithaml, V. A. (1993). A dynamic process model of service quality: from expectation to behavioural intentions. Journal of Marketing Research, 30(1), 7-27. http://dx.doi.org/10.2307/3172510

Churchill, L. (2010). Marketing Research Methodological Foundation.

Dar, R. I. \& Hu, Y. (2005). How Banks Manage CRM, A B2B Perspective.

Denscombe, M. (2000). Good the Research guide; for small scale-social research projects.

Duckett, L. (2001). The changing landscape of corporate e-banking: larger banks are driving the rate of change.

Dyche, J. (2001). The CRM Handbook: A Business Guide to Customer Relationship Management.

Feinberg, R., \& Kadam, R. (2002). E-CRM Web service attributes as determinants of customer satisfaction with retail web sites. International Journal of Service Industry Managment, 13(5), 432-451. http://dx.doi.org/10.1108/09564230210447922 
Fjermestad, J. \& Romano Jr, N. C. (2003). Electronic customer relationship management: revisiting the general principles of usability and resistance: an integrative implementation framework. Business Process Management Journal, 9(5), 572-591. http://dx.doi.org/10.1108/14637150310496695

Ghayomi, M. M. a. A. (2010). Statistics Analysis by SPSS.

Gilbert, D. C., \& Choi, K. C. (2003). Relationship marketing practice in relation to different bank ownership: a study of banks in Hong Kong. International journal of Bank Marketing, 21(3), 137-146. http://dx.doi.org/10.1108/02652320310469511

Graziano, A. M., \& Raulin, M. L. (2004). Research Methods-A Process of Inquiry.

Grönroos, C. (2000). Service Management and Marketing: A Customer Relationship Management Approach.

Hartman, J. (2000). Multiple Linear Regression.

Haverty, J. (1998). Electronic Commerce. A User's Guide.Ec.com Magazi.

Jelassi, T., \& Enders, A. ( 2004). Strategies for e-Business.

Joseph, F., \& Hair, J. (n.d.). Essentials of Business Research Methods.

Karimi, J., Somers, T. M., \& Gupta, Y. P. (2001). Impact of information technology management practices on customer service. Journal of Management Information Systems, 17(4), 125-158.

Kennedy, A. (2006). Electronic customers relationship management (eCRM): Opportunities and challanges in a digital world. Irish Marketing Review, 18(1\&2), 58-69.

Lavender, M. (2004). Maximising customer relationships and minimizing business risks. The international journal of bank marketing, 22.

Mittal, R. K., \& Kumra, R. (2001). E-CRM IN INDIAN BANKS. Delhi Business Review, 2(1).

Morris, M. H., Brunyee, J., \& Page, M. (1998). Relationship marketing in practice: myths and realities', industrial marketing management. Industrial marketing management, 27(4), 359-371. http://dx.doi.org/10.1016/S0019-8501(97)00079-5

Newell, F. (2000). Loyalty.com: CRM in the Age of Internet Marketing.

Parasuraman, A., Berry, L. L., \& Zeithaml, V. A. (1991). Understanding customer expectations of service.

Parasuraman, A., Zeithamal, V. A., \& Berry, L. L. (1988). SERVQUAL: A multiple-item scale for measuring consumer perceptions of service quality. Journal of Retailing, 64(1), 12-40.

Puccinelli, B. (1999). Bank Systems \& Technology. 36.

Research, F. (2001). Glossary. available at: www.forrester.com/Home/0.3257.1.FF.html.

Rigby, D. K., Reichheld, F., \& Schefter, P. (2002). Avoid the four perils of CRM. Harvard Business Review, (1), 101-109.

Rosen, K. (2001). Five myths of CRM.

Sascha, L. (2003). Modern Electronic Customer Relationship Management for Financial Service Providers.

Scullin, S., Allora, J., Lloyd, G. O., \& Fjermestad, J. (2002). Electronic customer relationship management: benefits, considerations, pitfalls and trends. Proceedings of the IS One World Conference. Las Vegas. pp. 3-5.

Shan, L. P., \& Lee, J. N. (2003). Using e-CRM for a unified view of the customer. Communication of the ACM, 46(4), 95-99. http://dx.doi.org/10.1145/641205.641212

Sims, D. (2000). What is CRM? available at: www.crmguru.com.

Singh, M. (2002). E-services and their role in B2C e-commerce. Managing Service Quality, 12(6), 434-446. http://dx.doi.org/10.1108/09604520210451911

Stefanou, C. J., Saramaniotis, C., \& Stafyla, A. (2003). CRM and customer-centric knowledge: an empirical research. Business Process Management Journal, 9(5), 617-634. http://dx.doi.org/10.1108/14637150310496721

Weiner, J. L., \& Tang, J. (2005). Multicollinearity in Customer Satisfaction Research.

Wong, Y. Y., \& Maher, T. E. (1998). Doing business with dragons of different breeds: some important differences between China and Japan. Management Research News, 21(4/5), 45-54. http://dx.doi.org/10.1108/01409179810781518 
Xu, Y., Yen, D. C., Lin, B., \& Chou, D. C. (2002). Adopting customer relationship management. Industrial Management \& Data System, 102(8), 442-452. http://dx.doi.org/10.1108/02635570210445871

Yin, R. K. (1984). Case study Resaerch-Design and Methods.

Yu-Lin, H. Y. a. (2005). Financial service personalization. Industrial management and data systems, 105.

Zeithaml, V., \& Bitner, M. J. (2000). Service Marketing.

Zikmund, G. W. (1994). Exploring Marketing Resaerch.

Zikmund, G. W. ( 2000). Business research methods. Oklahoma state university the Drydenpress, Harcourt college publishers.

Zineldin, M. (1995). International Journal of Bank Marketing, 13.

Zineldin, M. (1996). Bank strategic positioning and some determinants of bank selection. International Journal of Bank Marketing, 14(6), 12-22. http://dx.doi.org/10.1108/02652329610130136

Notes

Note 1. http://www.dobney.com//Knowledge/ck_definition.htm, accessed on 4 January 2011.

Note 2. http://www.businessdictionary.com/definition, accessed on 4 January 2011.

Note 3. http://www.businessdictionary.com/definition/delivery-timeliness.html, accessed on 4 January 2011.

Note 4. http://sbinfocanada.about.com/cs/managmeent/g/cashflowmgt.htm, accessed on 4 January 2011.

Note 5. http://www.marketbright.com/products/campaignmanagement.html, accessed on 4 January 2011.

Note 6. http://www.searchability.com/, accessed on 4 January 2011.

Note 7. http://www.bain.com/management_tools, accessed on 4 January 2011.

Note 8. http://knowledge.wharton.upenn.edu/special section, accessed on 4 January 2011.

Note 9. http://www.statsguides.bham.ac.uk/HT G/HTGtextonly/tfr/slr.htm, accessed on 11 September 2011

Note 10.http://www.entrepreneur.com/encyclopedia/term/82212.html

Note 11.http://www.businessdictionary.com/definition/competitive-advantage.html

Table 1. Relevant Literatures

\begin{tabular}{|c|c|c|c|}
\hline Scholars & E-CRM & E-CRM Benefits & Year \\
\hline $\begin{array}{l}\text { Brandon \& Randall, } \\
2007 \text { (Anumala \& } \\
\text { Reddy, 2007) }\end{array}$ & Service quality satisfied customers. & $\begin{array}{l}\text { - Increase Profitability } \\
\text { - Retain customers } \\
\text { - Increase Customer Loyalty }\end{array}$ & 2007 \\
\hline (Kennedy, 2006) & $\begin{array}{l}\text { E-CRM is considered as strategic technology centric } \\
\text { relationship marketing business framework. }\end{array}$ & $\begin{array}{l}\text { - Enhanced Customer Interaction and Relationship } \\
\text { - Managing customer Touch Points } \\
\text { - Personalization and E-Loyalty } \\
\text { - Source of Competitive Advantage }\end{array}$ & 2006 \\
\hline (Yu-Lin, 2005) & $\begin{array}{l}\text { Personalization is a strategy that can be easily } \\
\text { differentiated and which cannot be simulated by } \\
\text { competitors in the market. }\end{array}$ & $\begin{array}{l}\text { - Enhance sales } \\
\text { - Improve customer relationship } \\
\text { - Improving effectiveness and efficiency in serving } \\
\text { customers }\end{array}$ & 2005 \\
\hline $\begin{array}{l}\text { Jennifer, R. } 2005 \\
\text { (Anumala \& Reddy, } \\
\text { 2007) }\end{array}$ & $\begin{array}{l}\text { Convenience plays a vital role when selecting a brand } \\
\text { and if the customers are not happy with the convenience } \\
\text { of a particular brand. }\end{array}$ & $\begin{array}{l}\text { - Switching the brands by customers is brought about } \\
\text { by convenience }\end{array}$ & 2005 \\
\hline (Lavender, 2004) & $\begin{array}{l}\text { Identifying the needs of the customers and providing } \\
\text { them a best solution before he makes a request shows } \\
\text { excellence in service of the customers. }\end{array}$ & - Customer of the banks becoming choosier & 2004 \\
\hline $\begin{array}{l}\text { (Jelassi \& Enders, } \\
\text { 2004) }\end{array}$ & $\begin{array}{l}\text { E-CRM is the use of internet and IT applications used } \\
\text { to manage relationship with customers. } \\
\text { E-CRM elements: } \\
\text { 1. Customer selection } \\
\text { 2. Customer Acquisition } \\
\text { 3. Customer Retention } \\
\text { 4. Customer Extension }\end{array}$ & $\begin{array}{l}\text { - Increase customer satisfaction } \\
\text { - Acquire new customers } \\
\text { - Turn one-time customers to regular customers as } \\
\text { long as possible } \\
\text { - Maximize lifetime value of a customer }\end{array}$ & 2004 \\
\hline
\end{tabular}




\begin{tabular}{|c|c|c|c|}
\hline $\begin{array}{l}\text { (Jelassi \& Enders, } \\
\text { 2004) }\end{array}$ & & $\begin{array}{l}\text { - Create long-term relationship with customers with } \\
\text { minimum cost } \\
\text { - Reduce the customer defection rate } \\
\text { - Increase the profitability from low-profit customers } \\
\text { - Focuses on high-value customers } \\
\end{array}$ & 2004 \\
\hline $\begin{array}{l}\text { Michael, } 2003 \\
\text { (Anumala \& Reddy, } \\
\text { 2007) }\end{array}$ & $\begin{array}{l}\text { A convenient location is often considered o be an } \\
\text { additional service aspect of the core service. }\end{array}$ & $\begin{array}{l}\text { - Reduce travel costs } \\
\text { - Saving the time } \\
\text { - Increase Convenience }\end{array}$ & 2003 \\
\hline (Shan \& Lee, 2003) & $\begin{array}{l}\text { E-CRM expands the traditional CRM techniques by } \\
\text { integrating technologies of new electronic channels, } \\
\text { such as Web wireless and Voice technologies and } \\
\text { combines them with e-business applications into the } \\
\text { overall enterprise CRM strategy. }\end{array}$ & & 2003 \\
\hline (Fjermestad, 2003) & & $\begin{array}{l}\text { - Serve the customers in better way } \\
\text { - Retain valuable customers } \\
\text { - Enhance analytical capabilities in an organization }\end{array}$ & 2003 \\
\hline (Rigby, 2002) & $\begin{array}{l}\text { Vital and important key point is that E-CRM takes into } \\
\text { different forms, relying on the objectives of the } \\
\text { organizations. It is about arranging in a line business } \\
\text { process with strategies of customers provided back up } \\
\text { of software's. }\end{array}$ & & 2002 \\
\hline $\begin{array}{l}\text { Feinberb } 2002 \\
\text { (Anumala \& Reddy, } \\
2007 \text { ) }\end{array}$ & & $\begin{array}{l}\text { - Availability of amount } f \text { information to customer } \\
\text { browsing }\end{array}$ & 2002 \\
\hline (Singh, 2002) & $\begin{array}{l}\text { Faster processing the transaction by E-CRM, the fact } \\
\text { that e responses to customer queries, order } \\
\text { acknowledgement, delivery and payment information } \\
\text { via e- mails or automated responses are greatly } \\
\text { appreciated by customers }\end{array}$ & $\begin{array}{l}\text { - Strengthen the relationship between the supplier } \\
\text { and customers } \\
\text { - Increase the speed of processing the transaction } \\
\text { through e-Response }\end{array}$ & 2002 \\
\hline (Scullin, 2002) & $\begin{array}{l}\text { Believes that increased customer loyalty, information } \\
\text { accumulated by e- CRM system helps organizations to } \\
\text { identify the actual input cost of wining and retaining } \\
\text { long lasting relationships with customers. }\end{array}$ & & 2002 \\
\hline (Dyche, 2001) & $\begin{array}{l}\text { E-CRM is combination of software, hardware, } \\
\text { application and management commitment. }\end{array}$ & $\begin{array}{l}\text { - Improve customer service } \\
\text { - Develop a relationship } \\
\text { - Retain valuable customers } \\
\text { - Enhance delineation in customer's value }\end{array}$ & 2001 \\
\hline (Rosen, 2001) & $\begin{array}{l}\text { E-CRM is about people, process and technology and } \\
\text { these are key paramount to success. }\end{array}$ & & 2001 \\
\hline $\begin{array}{l}\text { Goldfinger, } 2001 \\
\text { (Anumala \& Reddy, } \\
\text { 2007) }\end{array}$ & $\begin{array}{l}\text { Believes safety was seen as a major barrier to Internet } \\
\text { banking. }\end{array}$ & $\begin{array}{l}\text { - Managing security with least repercussions by the } \\
\text { banks }\end{array}$ & 2001 \\
\hline (Research, 2001) & $\begin{array}{l}\text { E-CRM is the consolidation of traditional CRM with } \\
\text { e-business market place application. }\end{array}$ & & 2001 \\
\hline (Awad, 2000) & The most popular tool for customer service is e-mail. & $\begin{array}{l}\text { - Inexpensive } \\
\text { - Fast } \\
\text { - Providing quick and accurate information to all } \\
\text { customer }\end{array}$ & 2000 \\
\hline (Zeithaml, 2000) & $\begin{array}{l}\text { Identify two levels of expectations, desired service and } \\
\text { adequate service. }\end{array}$ & & 2000 \\
\hline (Newell, 2000) & $\begin{array}{l}\text { E-CRM systems use rich databanks of customer } \\
\text { information to manage the relationship with customers. }\end{array}$ & & 2000 \\
\hline (Sims, 2000) & $\begin{array}{l}\text { E-CRM systems support all stages of the interaction } \\
\text { with the customer for e.g. order, delivery and after-sales } \\
\text { service. E-CRM systems cover online banking, e-mail } \\
\text { knowledge bases that can be used to generate customer } \\
\text { profiles and customer will get personalize services. }\end{array}$ & - Help customer vs. bank interaction & 2000 \\
\hline (Haverty, 1998) & $\begin{array}{l}\text { E-CRM providing cost savings, opportunism, and } \\
\text { threats drive action and innovation even in conservative } \\
\text { banks. }\end{array}$ & $\begin{array}{l}\text { - Establishing new service delivery channel } \\
\text { - New markets for existing services (Loan, Letter of } \\
\text { credit, etc.) }\end{array}$ & 1998 \\
\hline
\end{tabular}




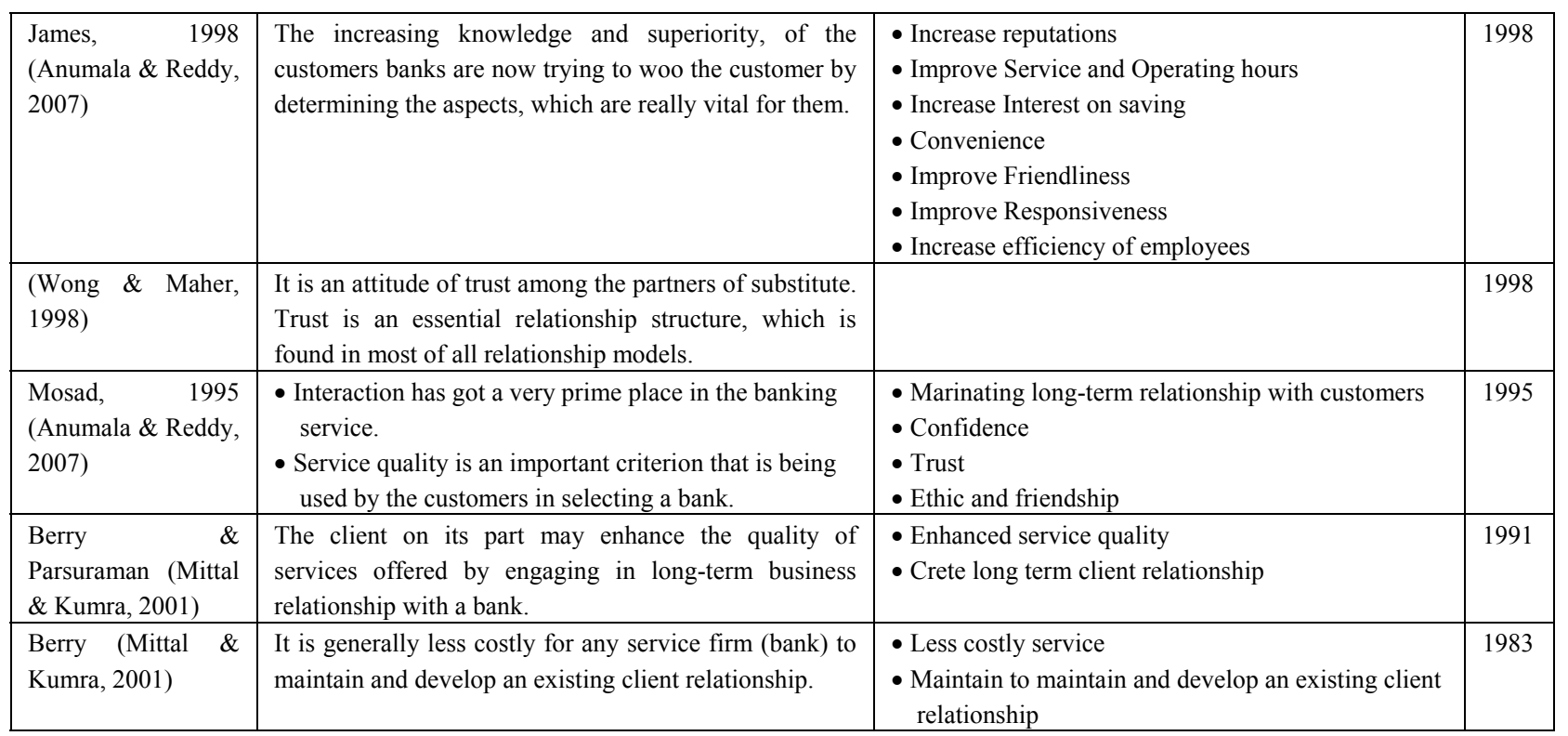

Table 2. E-CRM Benefits

\begin{tabular}{llllll}
\hline & Initial & Extraction & & Initial & Extraction \\
\hline Trust in E-CRM & 1.000 & .516 & International customers' satisfaction & 1.000 & .513 \\
Up to date of banks & 1.000 & .616 & Transaction Security & 1.000 & .556 \\
Accessibility to site & 1.000 & .415 & Proliferation of channels (e.g. Internet) & 1.000 & .553 \\
Customer Interactivity and Knowledge & 1.000 & .539 & Increased control over bank & 1.000 & .446 \\
Decrease of technology preparation & 1.000 & .440 & Improved cash flow management & 1.000 & .591 \\
On-time order fulfillment & 1.000 & .413 & Increase of transaction process speed & 1.000 & .470 \\
Personalized services or one to one & 1.000 & .487 & Search ability & 1.000 & .670 \\
services & 1.000 & .487 & Data Centralization & 1.000 & .614 \\
Services quality & 1.000 & .553 & & & \\
Increase of Safety & & & &
\end{tabular}

Note: Extraction Method: Principal Component Analysis.

Table 3. KMO and Bartlett's Test of E-CRM Benefits

\begin{tabular}{|l|l|l|}
\hline Kaiser-Meyer-Olkin Measure of Sampling Adequacy. & $\mathbf{. 9 2 0}$ \\
\hline \multirow{3}{*}{ Bartlett's Test of Sphericity } & Approx. Chi-Square & 2739.566 \\
\cline { 2 - 3 } & $\mathrm{df}$ & 136 \\
\cline { 2 - 3 } & Sig. & .000 \\
\hline
\end{tabular}

Table 4. The Conclusive E-CRM Benefits Affecting Customers' Satisfaction

\begin{tabular}{ll|l}
\hline Number of question & E-CRM benefits & \multicolumn{1}{c}{ Cronbach's Alpha } \\
\hline 17 & Proliferation of channels (e.g. Internet) & \\
8 & Banks being up to date & \\
14 & Services quality & \multirow{2}{*}{.754} \\
15 & International customers' satisfaction & \\
19 & Improved cash flow management & \\
23 & Increasment of Safety implementation & \\
16 & Transaction Security & \\
\hline
\end{tabular}


Table 5. E-CRM Competitive Advantages

\begin{tabular}{|c|c|c|c|c|c|}
\hline & Initial & Extraction & & Initial & Extraction \\
\hline $\begin{array}{l}\text { Preparation of up to date } \\
\text { technology }\end{array}$ & 1.000 & .469 & $\begin{array}{l}\text { Decrease of response } \\
\text { time }\end{array}$ & 1.000 & .659 \\
\hline Create Organizational culture & 1.000 & .479 & $\begin{array}{l}\text { Improved response to } \\
\text { customer activity }\end{array}$ & 1.000 & .621 \\
\hline Increase of price competition & 1.000 & .330 & $\begin{array}{l}\text { Utilization of Marketing } \\
\text { and Strategic factors }\end{array}$ & 1.000 & .624 \\
\hline $\begin{array}{l}\text { Decrease of product and service } \\
\text { complexity }\end{array}$ & 1.000 & .298 & $\begin{array}{l}\text { Creating } \quad \text { business } \\
\text { structure }\end{array}$ & 1.000 & .787 \\
\hline Innovation in banking services & 1.000 & .448 & $\begin{array}{l}\text { Drive down operating } \\
\text { costs }\end{array}$ & 1.000 & .402 \\
\hline
\end{tabular}

Note: Extraction Method: Principal Component Analysis.

Table 6. KMO and Bartlett's Test of Competitive Advantages

\begin{tabular}{|l|l|l|}
\hline Kaiser-Meyer-Olkin Measure of Sampling Adequacy. & $\mathbf{. 8 5 9}$ \\
\hline \multirow{3}{*}{ Bartlett's Test of Sphericity } & Approx. Chi-Square & 1717.735 \\
\cline { 2 - 3 } & df & 55 \\
\cline { 2 - 3 } & Sig. & .000 \\
\hline
\end{tabular}

Table 7. The Conclusive E-CRM Benefits Affecting on Customer Satisfaction in Choosing the Banks to Do Their Financial and Business Works

\begin{tabular}{lll}
\hline Number of question & E-CRM competitive advantages & Cronbach's Alpha \\
\hline 30 & Improve integrated customer profitability & \\
33 & Utilization of Marketing and Strategic factors & .762 \\
34 & Creating business structure & \\
31 & Decrease of response time & \\
32 & Improve response to customer activity & \\
\hline
\end{tabular}

Table 8. Normality Test

\begin{tabular}{llll}
\hline & & Benefits of E-CRM & Competitive advantages of E-CRM \\
\hline $\mathrm{N}$ & & 490 & 490 \\
Normal Parameters & a, b & 4.2839 & 4.2261 \\
& Mean & .60245 & .65095 \\
& Std. Deviation & .118 & .133 \\
Most Extreme Differences & Absolute & .117 & .117 \\
& Positive & -.118 & -.133 \\
Kolmogorov-Smirnov Z & Negative & 2.601 & 2.954 \\
Asymp. Sig. (2-tailed) & & .000 & .000 \\
\hline
\end{tabular}

Note: ${ }^{\text {a. }}$ Test distribution is Normal. ${ }^{\text {b. }}$ calculated from data.

Table 9. Normality Test for E-CRM Competitive Advantages

\begin{tabular}{lccccc}
\hline & Minimum & Maximum & Mean & Std. Deviation & N \\
\hline Predicted Value & 2.2449 & 4.9037 & 4.4112 & .44031 & 484 \\
Residual & -3.08370 & 1.73413 & .00000 & .71589 & 484 \\
Std. Predicted Value & -4.920 & 1.119 & .000 & 1.000 & 484 \\
Std. Residual & -4.285 & 2.410 & $\mathbf{. 0 0 0}$ & $\mathbf{. 9 9 5}$ & 484 \\
\hline
\end{tabular}

Note: Dependent Variable: satisfying customer by E-CRM. 
Table 10. Friedman Test Statistics

\begin{tabular}{|c|c|}
\hline N of Items & 480 \\
\hline Cronbach's Alpha & 370.355 \\
\hline Df & 6 \\
\hline Asymp. Sig. & $\mathbf{. 0 0 0}$ \\
\hline
\end{tabular}

Table 11. The Most Significant E-CRM Benefits

\begin{tabular}{lc}
\hline E-CRM benefits & Mean Rank \\
\hline Up to date of banks & 4.53 \\
Services quality & 4.37 \\
International customers' satisfaction & 3.27 \\
Transaction Security & 4.50 \\
Proliferation of channels (e.g. Internet) & 3.99 \\
Increasment of Safety implementation & 4.30 \\
Improved cash flow management & 3.04 \\
\hline
\end{tabular}

Table 12. Normality Test for E-CRM Benefits

\begin{tabular}{llllll}
\hline & Minimum & Maximum & Mean & Std. Deviation & N \\
\hline Predicted Value & 2.1374 & 4.8314 & 4.4621 & .46056 & 483 \\
Residual & -3.60545 & 2.48000 & .00582 & .67867 & 483 \\
Std. Predicted Value & -5.096 & .803 & -.005 & 1.009 & 483 \\
Std. Residual & -5.328 & 3.665 & $\mathbf{. 0 0 9}$ & $\mathbf{1 . 0 0 3}$ & 483 \\
\hline
\end{tabular}

Note: Dependent Variable: satisfying customer by ECRM.

Table 13. The E-CRM Benefits That Has Positively Effects on Customer Satisfaction

\begin{tabular}{|c|c|c|c|c|c|c|}
\hline \multirow{2}{*}{\multicolumn{2}{|c|}{ Model }} & \multicolumn{2}{|c|}{ Un standardized Coefficients } & \multirow{2}{*}{$\begin{array}{l}\text { Standardized Coefficients } \\
\text { Beta }\end{array}$} & \multirow{2}{*}{ t } & \multirow{2}{*}{ Sig. } \\
\hline & & B & Std. Error & & & \\
\hline \multirow{2}{*}{1} & (Constant) & 2.557 & .163 & & 15.669 & .000 \\
\hline & increasing safety & .430 & .036 & .479 & 11.932 & .000 \\
\hline \multirow{3}{*}{2} & (Constant) & 2.033 & .178 & & 11.411 & .000 \\
\hline & increasing safety & .310 & .040 & .345 & 7.807 & .000 \\
\hline & Proliferation of channels (e.g. Internet) & .244 & .039 & .275 & 6.225 & .000 \\
\hline \multirow{4}{*}{3} & (Constant) & 1.652 & .204 & & 8.092 & .000 \\
\hline & increasing safety & .258 & .042 & .287 & 6.197 & .000 \\
\hline & Proliferation of channels (e.g. Internet) & .187 & .042 & .211 & 4.488 & .000 \\
\hline & Up to date of banks & .188 & .051 & .176 & 3.684 & .000 \\
\hline \multirow{5}{*}{4} & (Constant) & 1.464 & .219 & & 6.679 & .000 \\
\hline & increasing safety & .226 & .044 & .252 & 5.166 & .000 \\
\hline & Proliferation of channels (e.g. Internet) & .172 & .042 & .194 & 4.097 & .000 \\
\hline & Up to date of banks & .168 & .052 & .157 & 3.255 & .001 \\
\hline & Transaction Security & .107 & .047 & .105 & 2.289 & .023 \\
\hline
\end{tabular}

Note: Dependent Variable: satisfying customer by ECRM. 
Table 14. The Association between E-CRM Benefits

\begin{tabular}{|c|c|c|c|c|c|c|c|c|c|}
\hline & $\begin{array}{l}\text { Up to } \\
\text { date } \\
\text { of } \\
\text { banks }\end{array}$ & $\begin{array}{l}\text { Services } \\
\text { quality }\end{array}$ & $\begin{array}{l}\text { International } \\
\text { customers' } \\
\text { satisfaction }\end{array}$ & $\begin{array}{l}\text { Transaction } \\
\text { Security }\end{array}$ & $\begin{array}{l}\text { Proliferation } \\
\text { of channels } \\
\text { (e.g. } \\
\text { Internet) }\end{array}$ & $\begin{array}{l}\text { increasing } \\
\text { safety }\end{array}$ & $\begin{array}{l}\text { Improved } \\
\text { cash flow } \\
\text { managem- } \\
\text { ent }\end{array}$ \\
\hline \multirow{21}{*}{$\begin{array}{l}\text { Spearman's } \\
\text { rho }\end{array}$} & \multirow{3}{*}{$\begin{array}{l}\text { Up to date } \\
\text { of banks }\end{array}$} & $\begin{array}{l}\text { Correlation } \\
\text { Coefficient }\end{array}$ & 1.000 & $.369^{* *}$ & $.198^{* *}$ & $.363^{* *}$ & $.446^{* *}$ & $.421^{* *}$ & $.123^{* *}$ \\
\hline & & Sig. (2-tailed) & . & .000 & .000 & .000 & .000 & .000 & .006 \\
\hline & & $\mathrm{N}$ & 490 & 490 & 488 & 489 & 488 & 486 & 489 \\
\hline & \multirow{3}{*}{$\begin{array}{l}\text { Services } \\
\text { quality }\end{array}$} & $\begin{array}{l}\text { Correlation } \\
\text { Coefficient }\end{array}$ & $.369^{* *}$ & 1.000 & $.269^{* *}$ & $.398^{* *}$ & $.420^{* *}$ & $.412^{* *}$ & $.132^{* *}$ \\
\hline & & Sig. (2-tailed) & .000 & . & .000 & .000 & .000 & .000 & .004 \\
\hline & & $\mathrm{N}$ & 490 & 490 & 488 & 489 & 488 & 486 & 489 \\
\hline & \multirow{3}{*}{$\begin{array}{l}\text { International } \\
\text { customers' } \\
\text { satisfaction }\end{array}$} & $\begin{array}{l}\text { Correlation } \\
\text { Coefficient }\end{array}$ & $.198^{* *}$ & $.269^{* *}$ & 1.000 & $.232^{* *}$ & $.276^{* *}$ & $.209^{* *}$ & $.381^{* *}$ \\
\hline & & \begin{tabular}{|l|} 
Sig. (2-tailed) \\
\end{tabular} & .000 & .000 & . & .000 & .000 & .000 & .000 \\
\hline & & $\mathrm{N}$ & 488 & 488 & 488 & 487 & 486 & 484 & 487 \\
\hline & \multirow{3}{*}{$\begin{array}{l}\text { Transaction } \\
\text { Security }\end{array}$} & $\begin{array}{l}\text { Correlation } \\
\text { Coefficient }\end{array}$ & $.363^{* *}$ & $.398^{* *}$ & $.232^{* *}$ & 1.000 & $.366^{* *}$ & $.477^{* *}$ & $.158^{* *}$ \\
\hline & & Sig. (2-tailed) & .000 & .000 & .000 &. & .000 & .000 & .000 \\
\hline & & $\mathrm{N}$ & 489 & 489 & 487 & 489 & 487 & 485 & 488 \\
\hline & \multirow{3}{*}{$\begin{array}{l}\text { Proliferation } \\
\text { of channels } \\
\text { (e.g. Internet) }\end{array}$} & $\begin{array}{l}\text { Correlation } \\
\text { Coefficient }\end{array}$ & $.446^{* *}$ & $.420^{* *}$ & $.276^{* *}$ & $.366^{* *}$ & 1.000 & $.407^{* *}$ & $.154^{* *}$ \\
\hline & & Sig. (2-tailed) & .000 & .000 & .000 & .000 &. & .000 & .001 \\
\hline & & $\mathrm{N}$ & 488 & 488 & 486 & 487 & 488 & 484 & 487 \\
\hline & \multirow{3}{*}{$\begin{array}{l}\text { increasing } \\
\text { safety }\end{array}$} & $\begin{array}{l}\text { Correlation } \\
\text { Coefficient }\end{array}$ & $.421^{* *}$ & $.412^{* *}$ & $.209^{* *}$ & $.477^{* *}$ & $.407^{* *}$ & 1.000 & $.139^{* *}$ \\
\hline & & Sig. (2-tailed) & .000 & .000 & .000 & .000 & .000 & & .002 \\
\hline & & $\mathrm{N}$ & 486 & 486 & 484 & 485 & 484 & 486 & 485 \\
\hline & \multirow{3}{*}{$\begin{array}{l}\text { Improved } \\
\text { cash flow } \\
\text { management }\end{array}$} & $\begin{array}{l}\text { Correlation } \\
\text { Coefficient }\end{array}$ & $.123^{* *}$ & $.132^{* *}$ & $.381^{* *}$ & $.158^{* *}$ & $.154^{* *}$ & $.139^{* *}$ & 1.000 \\
\hline & & Sig. (2-tailed) & .006 & .004 & .000 & .000 & .001 & .002 &. \\
\hline & & $\mathrm{N}$ & 489 & 489 & 487 & 488 & 487 & 485 & 489 \\
\hline
\end{tabular}

Note: ** Correlation is significant at the 0.01 level (2-tailed).

Table 15. Collinearity Diagnostics

\begin{tabular}{|c|c|c|c|c|c|c|c|c|c|c|}
\hline \multirow[b]{2}{*}{ Model } & \multirow[b]{2}{*}{ Dimension } & \multirow[b]{2}{*}{$\begin{array}{l}\text { Eigen } \\
\text { value }\end{array}$} & \multirow{2}{*}{$\begin{array}{l}\text { Condition } \\
\text { Index }\end{array}$} & \multicolumn{5}{|c|}{ Variance Proportions } & \multicolumn{2}{|c|}{$\begin{array}{l}\text { Collinearity } \\
\text { Statistics }\end{array}$} \\
\hline & & & & (Constant) & $\begin{array}{l}\text { Increasing } \\
\text { safety }\end{array}$ & $\begin{array}{l}\text { Proliferation of } \\
\text { channels (e.g. } \\
\text { Internet) }\end{array}$ & $\begin{array}{l}\text { Up to date } \\
\text { of banks }\end{array}$ & $\begin{array}{l}\text { Transaction } \\
\text { Security }\end{array}$ & Tolerance & VIF \\
\hline \multirow{2}{*}{1} & 1 & 1.980 & 1.000 & .01 & .01 & & & & & \\
\hline & 2 & .020 & 9.895 & .99 & .99 & & & & 1.000 & 1.000 \\
\hline \multirow{3}{*}{2} & 1 & 2.958 & 1.000 & .00 & .00 & .00 & & & & \\
\hline & 2 & .022 & 11.593 & .34 & .14 & .98 & & & .764 & 1.309 \\
\hline & 3 & .020 & 12.103 & .66 & .86 & .02 & & & .764 & 1.309 \\
\hline \multirow{4}{*}{3} & 1 & 3.945 & 1.000 & .00 & .00 & .00 & .00 & & & \\
\hline & 2 & .022 & 13.320 & .30 & .02 & .86 & .02 & & .676 & 1.478 \\
\hline & 3 & .021 & 13.826 & .24 & .94 & .05 & .03 & & .659 & 1.518 \\
\hline & 4 & .013 & 17.745 & .46 & .04 & .09 & .95 & & .641 & 1.561 \\
\hline \multirow{5}{*}{4} & 1 & 4.928 & 1.000 & .00 & .00 & .00 & .00 & .00 & & \\
\hline & 2 & .024 & 14.399 & .13 & .00 & .81 & .00 & .13 & .607 & 1.647 \\
\hline & 3 & .021 & 15.451 & .23 & .82 & .04 & .03 & .00 & .643 & 1.556 \\
\hline & 4 & .016 & 17.695 & .08 & .09 & .09 & .26 & .76 & .622 & 1.608 \\
\hline & 5 & .012 & 20.103 & .56 & .09 & .07 & .71 & .11 & .683 & 1.465 \\
\hline
\end{tabular}


Table 16. Friedman Test Statistics

\begin{tabular}{|c|c|}
\hline N of Items & 487 \\
\hline Cronbach's Alpha & 337.571 \\
\hline Df & 4 \\
\hline Asymp. Sig. & $\mathbf{. 0 0 0}$ \\
\hline
\end{tabular}

Table 17. The Most Vital E-CRM Competitive Advantages

\begin{tabular}{lc}
\hline E-CRM competitive advantages & Mean Rank \\
\hline Improve integrated customer profitability & 3.07 \\
Decrease of response time & 3.57 \\
Improve response to customer activity & 3.37 \\
Utilization of Marketing and Strategic factors & 2.67 \\
Creating business structure & 2.32 \\
\hline
\end{tabular}

Table 18. The Association between E-CRM Benefits

\begin{tabular}{|c|c|c|c|c|c|c|c|}
\hline & & & $\begin{array}{l}\text { Improve integrated } \\
\text { customer } \\
\text { profitability }\end{array}$ & $\begin{array}{l}\text { Decrease of } \\
\text { response } \\
\text { time }\end{array}$ & $\begin{array}{l}\text { Improve } \\
\text { response to } \\
\text { customer } \\
\text { activity } \\
\end{array}$ & $\begin{array}{l}\text { Utilization of } \\
\text { Marketing } \\
\text { and Strategic } \\
\text { factors }\end{array}$ & $\begin{array}{l}\text { Creating } \\
\text { business } \\
\text { structure }\end{array}$ \\
\hline \multirow{15}{*}{$\begin{array}{l}\text { Spear- } \\
\text { man's } \\
\text { rho }\end{array}$} & \multirow{3}{*}{$\begin{array}{l}\text { Improve integrated } \\
\text { customer } \\
\text { profitability }\end{array}$} & Correlation Coefficient & 1.000 & $.395^{* *}$ & $.403^{* *}$ & $.372^{* *}$ & $.345^{* *}$ \\
\hline & & Sig. (2-tailed) & & .000 & .000 & .000 & .000 \\
\hline & & $\mathrm{N}$ & 490 & 490 & 490 & 489 & 488 \\
\hline & \multirow{3}{*}{$\begin{array}{l}\text { Decrease of response } \\
\text { time }\end{array}$} & Correlation Coefficient & $.395^{* *}$ & 1.000 & $.580^{* *}$ & $.331^{* *}$ & $.239^{* *}$ \\
\hline & & Sig. (2-tailed) & .000 & & .000 & .000 & .000 \\
\hline & & $\mathrm{N}$ & 490 & 490 & 490 & 489 & 488 \\
\hline & \multirow{3}{*}{$\begin{array}{l}\text { Improve response to } \\
\text { customer activity }\end{array}$} & Correlation Coefficient & $.403^{* *}$ & $.580^{* *}$ & 1.000 & $.352^{* *}$ & $.309^{* *}$ \\
\hline & & Sig. (2-tailed) & .000 & .000 & & .000 & .000 \\
\hline & & $\mathrm{N}$ & 490 & 490 & 490 & 489 & 488 \\
\hline & \multirow{3}{*}{\begin{tabular}{|l} 
Utilization of \\
Marketing and \\
Strategic factors \\
\end{tabular}} & Correlation Coefficient & $.372^{* *}$ & $.331^{* *}$ & $.352^{* *}$ & 1.000 & $.595^{* *}$ \\
\hline & & Sig. (2-tailed) & .000 & .000 & .000 & \begin{tabular}{|l|}
. \\
\end{tabular} & .000 \\
\hline & & $\mathrm{N}$ & 489 & 489 & 489 & 489 & 487 \\
\hline & \multirow{3}{*}{$\begin{array}{l}\text { Creating business } \\
\text { structure }\end{array}$} & Correlation Coefficient & $.345^{* *}$ & $.239^{* *}$ & $.309^{* *}$ & $.595^{* *}$ & 1.000 \\
\hline & & Sig. (2-tailed) & .000 & .000 & .000 & .000 & \\
\hline & & $\mathrm{N}$ & 488 & 488 & 488 & 487 & 488 \\
\hline
\end{tabular}

Note: **. Correlation is significant at the 0.01 level (2-tailed). 
Table 19. Collinearity Diagnostics

\begin{tabular}{|c|c|c|c|c|c|c|c|c|c|c|c|}
\hline \multirow[b]{2}{*}{ Model } & \multirow[b]{2}{*}{$\begin{array}{l}\text { Dime- } \\
\text { nsion }\end{array}$} & \multirow[b]{2}{*}{$\begin{array}{l}\text { Eigen } \\
\text { value }\end{array}$} & \multirow[b]{2}{*}{$\begin{array}{l}\text { Condition } \\
\text { Index }\end{array}$} & \multicolumn{6}{|c|}{ Variance Proportions } & \multicolumn{2}{|c|}{$\begin{array}{l}\text { Collinearity } \\
\text { Statistics }\end{array}$} \\
\hline & & & & $\begin{array}{l}\text { (Con- } \\
\text { stant) }\end{array}$ & \begin{tabular}{|l} 
Improve \\
integrated \\
customer \\
profitability
\end{tabular} & $\begin{array}{l}\text { Decrease of } \\
\text { response } \\
\text { time }\end{array}$ & $\begin{array}{l}\text { Creating } \\
\text { business } \\
\text { structure }\end{array}$ & $\begin{array}{l}\text { Improve } \\
\text { response to } \\
\text { customer } \\
\text { activity }\end{array}$ & $\begin{array}{l}\text { Utilization of } \\
\text { Marketing and } \\
\text { Strategic factors }\end{array}$ & $\begin{array}{l}\text { Toler- } \\
\text { ance }\end{array}$ & VIF \\
\hline 1 & $\begin{array}{l}1 \\
2\end{array}$ & $\begin{array}{l}1.977 \\
.023\end{array}$ & $\begin{array}{l}1.000 \\
9.301\end{array}$ & $\begin{array}{l}.01 \\
.99\end{array}$ & $\begin{array}{l}.01 \\
.99\end{array}$ & & & & & 1.000 & 1.000 \\
\hline 2 & $\begin{array}{l}1 \\
2 \\
3\end{array}$ & $\begin{array}{l}2.963 \\
.025 \\
.013 \\
\end{array}$ & $\begin{array}{l}1.000 \\
10.949 \\
15.356 \\
\end{array}$ & $\begin{array}{l}.00 \\
.22 \\
.78 \\
\end{array}$ & $\begin{array}{l}.00 \\
.97 \\
.03 \\
\end{array}$ & $\begin{array}{l}.00 \\
.08 \\
.91 \\
\end{array}$ & & & & $\begin{array}{l}.804 \\
.804\end{array}$ & $\begin{array}{l}1.244 \\
1.244 \\
\end{array}$ \\
\hline 3 & $\begin{array}{l}1 \\
2 \\
3 \\
4\end{array}$ & $\begin{array}{l}3.916 \\
.047 \\
.025 \\
.012 \\
\end{array}$ & $\begin{array}{l}1.000 \\
9.111 \\
12.587 \\
17.760 \\
\end{array}$ & $\begin{array}{l}.00 \\
.03 \\
.21 \\
.77\end{array}$ & $\begin{array}{l}.00 \\
.06 \\
.90 \\
.04\end{array}$ & $\begin{array}{l}.00 \\
.05 \\
.08 \\
.87\end{array}$ & $\begin{array}{l}.00 \\
.98 \\
.00 \\
.02\end{array}$ & & & $\begin{array}{l}.751 \\
.796 \\
.887 \\
\end{array}$ & $\begin{array}{l}1.331 \\
1.256 \\
1.127 \\
\end{array}$ \\
\hline 4 & $\begin{array}{l}1 \\
2 \\
3 \\
4 \\
5\end{array}$ & $\begin{array}{l}4.898 \\
.050 \\
.026 \\
.016 \\
.010 \\
\end{array}$ & $\begin{array}{l}1.000 \\
9.936 \\
13.737 \\
17.508 \\
22.063 \\
\end{array}$ & $\begin{array}{l}.00 \\
.01 \\
.08 \\
.75 \\
.16 \\
\end{array}$ & $\begin{array}{l}.00 \\
.02 \\
.97 \\
.00 \\
.01 \\
\end{array}$ & $\begin{array}{l}.00 \\
.02 \\
.03 \\
.02 \\
.93 \\
\end{array}$ & $\begin{array}{l}.00 \\
.97 \\
.00 \\
.01 \\
.02 \\
\end{array}$ & $\begin{array}{l}.00 \\
.02 \\
.05 \\
.44 \\
.49 \\
\end{array}$ & & $\begin{array}{l}.726 \\
.576 \\
.866 \\
.568 \\
\end{array}$ & $\begin{array}{l}1.378 \\
1.736 \\
1.154 \\
1.760 \\
\end{array}$ \\
\hline 5 & $\begin{array}{l}1 \\
2 \\
3 \\
4 \\
5 \\
6\end{array}$ & $\begin{array}{l}5.865 \\
.060 \\
.026 \\
.023 \\
.016 \\
.010\end{array}$ & $\begin{array}{l}1.000 \\
9.926 \\
14.982 \\
16.007 \\
19.171 \\
24.153\end{array}$ & $\begin{array}{l}.00 \\
.02 \\
.06 \\
.03 \\
.73 \\
.16\end{array}$ & $\begin{array}{l}.00 \\
.04 \\
.93 \\
.03 \\
.00 \\
.01\end{array}$ & $\begin{array}{l}.00 \\
.03 \\
.03 \\
.00 \\
.02 \\
.92\end{array}$ & $\begin{array}{l}.00 \\
.30 \\
.02 \\
.64 \\
.02 \\
.02\end{array}$ & $\begin{array}{l}.00 \\
.03 \\
.05 \\
.00 \\
.44 \\
.48\end{array}$ & $\begin{array}{l}.00 \\
.13 \\
.04 \\
.83 \\
.00 \\
.00\end{array}$ & $\begin{array}{l}.719 \\
.571 \\
.580 \\
.564 \\
.553\end{array}$ & $\begin{array}{l}1.392 \\
1.750 \\
1.725 \\
1.774 \\
1.807\end{array}$ \\
\hline
\end{tabular}

Note: Dependent Variable: Importance of competitive advantage in E-CRM implementation.

Table 20. The E-CRM Competitive Advantages That Has Positively Effects on Customer Satisfaction

\begin{tabular}{|c|c|c|c|c|c|c|}
\hline \multicolumn{2}{|c|}{ Model } & \multicolumn{2}{|c|}{$\begin{array}{l}\text { Un standardized } \\
\text { Coefficients }\end{array}$} & \multirow{2}{*}{$\begin{array}{l}\text { Standardized } \\
\text { Coefficients } \\
\text { Beta } \\
\end{array}$} & \multirow[t]{2}{*}{$\mathbf{t}$} & \multirow[t]{2}{*}{ Sig. } \\
\hline & & B & Std. Error & & & \\
\hline \multirow{2}{*}{1} & (Constant) & 2.886 & .165 & & 17.463 & .000 \\
\hline & Improve integrated customer profitability & .356 & .038 & .395 & 9.448 & .000 \\
\hline \multirow{3}{*}{2} & (Constant) & 1.929 & .224 & & 8.606 & .000 \\
\hline & Improve integrated customer profitability & .247 & .041 & .274 & 6.091 & .000 \\
\hline & Decrease of response time & .311 & .051 & .273 & 6.073 & .000 \\
\hline \multirow{4}{*}{3} & (Constant) & 1.615 & .227 & & 7.114 & .000 \\
\hline & Improve integrated customer profitability & .193 & .041 & .215 & 4.730 & .000 \\
\hline & Decrease of response time & .286 & .050 & .252 & 5.707 & .000 \\
\hline & Creating business structure & .173 & .034 & .214 & 5.119 & .000 \\
\hline \multirow{5}{*}{4} & (Constant) & 1.494 & .231 & & 6.474 & .000 \\
\hline & Improve integrated customer profitability & .174 & .041 & .194 & 4.214 & .000 \\
\hline & Decrease of response time & .209 & .059 & .184 & 3.561 & .000 \\
\hline & Creating business structure & .160 & .034 & .198 & 4.701 & .000 \\
\hline & Improve response to customer activity & .136 & .054 & .130 & 2.510 & .012 \\
\hline \multirow{6}{*}{5} & (Constant) & 1.448 & .231 & & 6.278 & .000 \\
\hline & Improve integrated customer profitability & .165 & .041 & .183 & 3.983 & .000 \\
\hline & Decrease of response time & .196 & .059 & .173 & 3.351 & .001 \\
\hline & Creating business structure & .106 & .042 & .130 & 2.550 & .011 \\
\hline & Improve response to customer activity & .125 & .054 & .120 & 2.310 & .021 \\
\hline & Utilization of Marketing and Strategic factors & .099 & .043 & .120 & 2.283 & .023 \\
\hline
\end{tabular}

Note: Dependent Variable: satisfying customer by ECRM. 


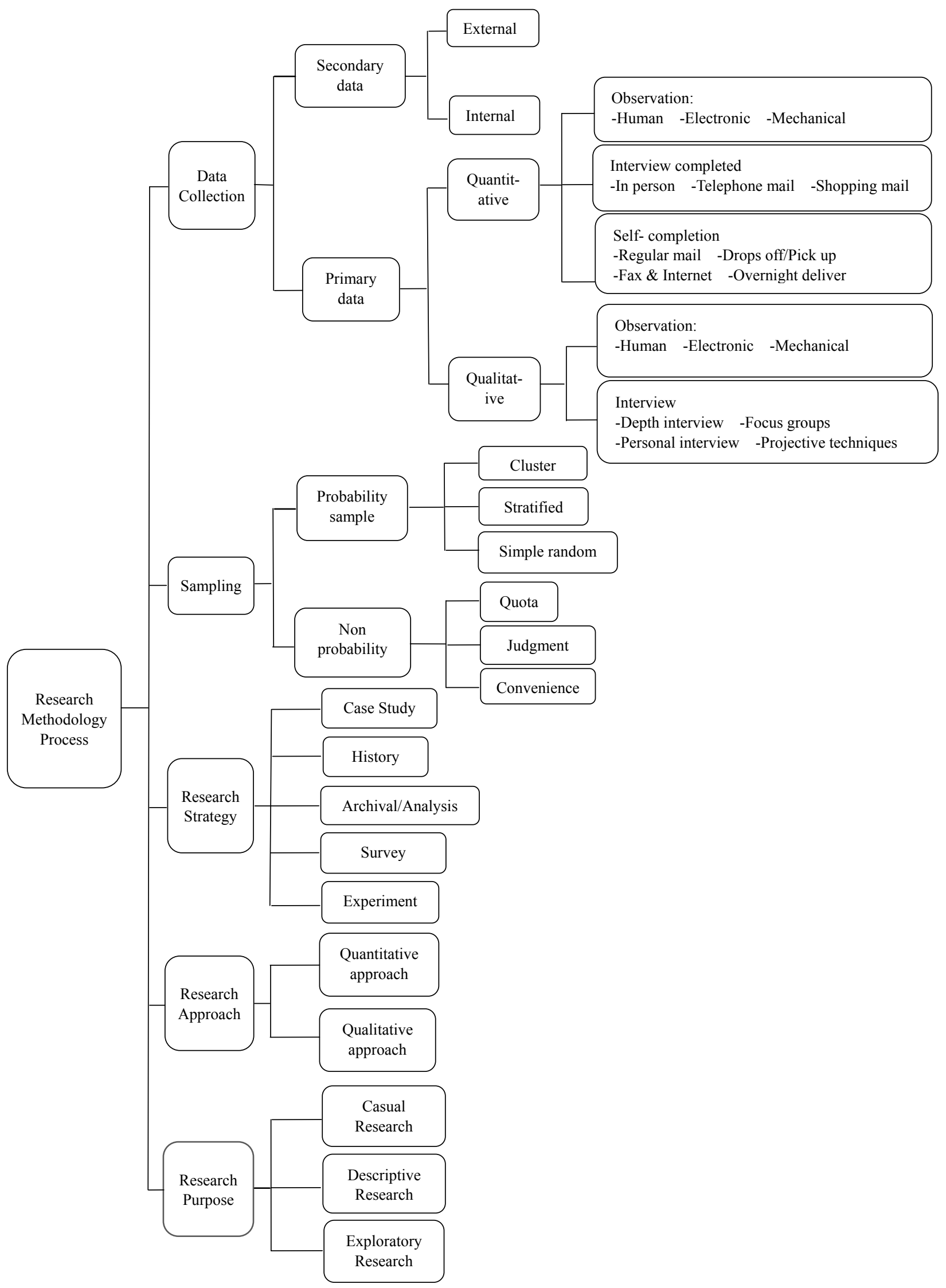

Figure 1. Summary of Research Methodology

Source: (Churchill, 2010) \& (Joseph F.Hair). 


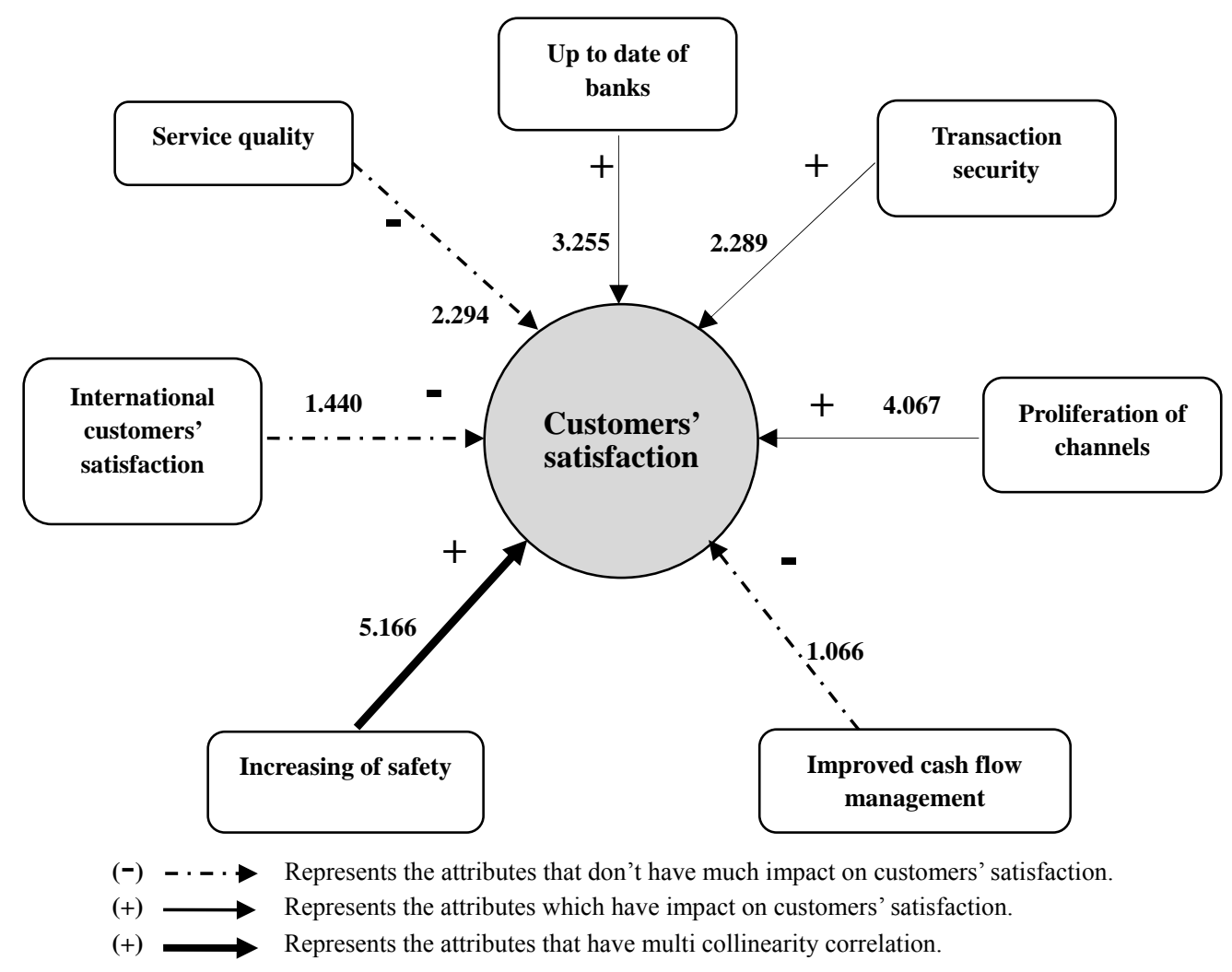

Figure 2. Model of E-CRM Benefits and Customers' Satisfaction

Source: Author's own construction.

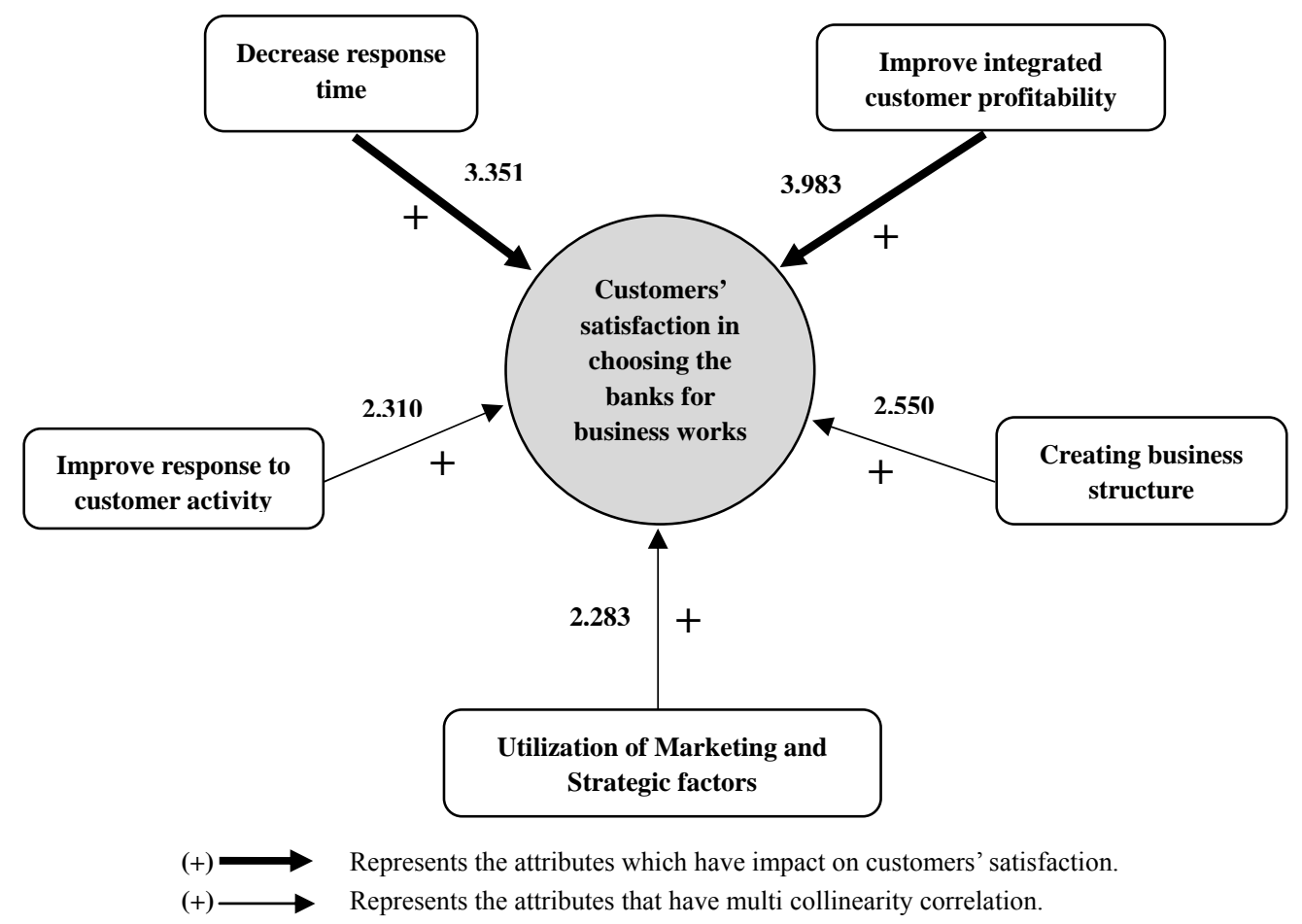

Figure 3. Model of E-CRM Competitive Advantages and Customers' Satisfaction Source: Author's own construction. 